\title{
Idäntutkimus 2022: Kirjoittajakutsu
}

Haluaisitko julkaista Venäjään tai Itä-Eurooppaan liittyvää tutkimustasi suomeksi? Idäntutkimus on ainoa suomenkielinen Venäjään ja Itä-Eurooppaan keskittyvä tieteellinen aikakauslehti, joka julkaisee vertaisarvioitujen artikkelien lisäksi esseitä, kolumneja, väitöslektioita, seminaariraportteja, keskustelunavauksia ja kirja-arvioita eri tieteenaloilta. Lehti ilmestyy neljä kertaa vuodessa, ja vuoden 2022 ensimmäisen vapaan teeman numeron jälkeen julkaistaan teemanumerot Ylirajaisuus, Valko-Venäjä ja Ääni. Mikäli kiinnostuit, löydät lisätietoja, kirjoittajaohjeet sekä jo julkaistuja numeroita Idäntutkimuksen nettisivuilta: https:// journal.fi/idantutkimus

\section{1/2022: Vapaa teema}

Vuoden ensimmäisellä numerolla ei ole määättyä teemaa, ja voit tarjota lehteen tekstejäsi laajalla otteella. Vertaisarvioitavien artikkeleiden dl: 5.11.2021. Vertaisarvioimattomien tekstien dl: 15.1.2022

\section{2/2022: Ylirajaisuus}

Vuoden toinen numero keskittyy niin rajoja ylittäviin ilmiöihin kuin ylirajaisuutta tutkimuksellisena lähestymistapana korostaviin näkökulmiin. Numerossa keskiössä ovat ihmisten, ideoiden ja aatteiden siirtymät, samoin kuin raja-aitoja ylittävä tiede ja taide. Vertaisarvioitavien artikkeleiden $\mathrm{dl}$ : 1.2.2022. Vertaisarvioimattomien tekstien dl: 31.3.2022.

\section{3/2022: Valko-Venäjä}

Valko-Venäjän kireän poliittisen tilanteen pudottua pois nopeatempoisimman uutisvirran kyydistä Idäntutkimus omistaa kolmannen numeronsa tälle epävarmuuden tilassa jatkavalle maalle. Tekstit, jotka tarkastelevat niin Valko-Venäjän nykytilaa kuin menneisyyttä, samoin kuin kulttuuria laajasti ymmärtäen, ovat tervetulleita. Vertaisarvioitavien artikkeleiden dl: 15.4.2022. Vertaisarvioimattomien tekstien dl: 31.7.2022.

\section{4/2022: Ääni}

Vuoden viimeinen numero Ä̈̈ni kutsuu kirjoittajia pohtimaan ääntä sekä konkreettisten että symbolisten merkitysten kautta. Mitä ääni(oikeus) merkitsee ihmisille? Millaisia ääniä yhteiskunnassa kuuluu ja millaisia jää kuulumatta? Entä miten äänestä luodaan musiikkia ja muutakin taidetta, joiden merkitykset ulottuvat sanoja pidemmälle? Vertaisarvioitavien artikkeleiden dl: 15.8.2022. Vertaisarvioimattomien tekstien dl: 1.10 .2022 .

Lisätietoja saat päätoimittajalta tai toimitussihteeriltä:

Päätoimittaja Mika Perkiömäki mika.perkiomaki@helsinki.fi Toimitussihteeri Jari Parkkinen jari.v.parkkinen@jyu.fi 